\title{
Corporate Governance: Theory and Practice Impact of Corporate Governance on Firm Performance
}

\author{
Rizwan Khalid ${ }^{1}$, Tayyab Ali $^{2}$, Muhammad Usman Javed ${ }^{* 3}$, \\ 1,2,3 Riphah International University, Islamabad, Pakistan
}

\begin{abstract}
Corporate governance is one of most widely researched topics in the different fields of management sciences. Additionally, governance plays equal role in firm performance in all countries especially developing countries become more important like Pakistan which contain equal importance to be studied with in subject to developed countries as to be well known in governance values, moreover there is increased interest to observe impact of corporate governance on different dimensions of firm performance. The objective of this paper is to underlay the corporate governance theories and practices and we have studied and try to analysis the impact of corporate governance structure on firm performance. This is a descriptive type of study in which we analysis different studies as coded all studies as they may have different implications in developed countries but here they may have different results as in developing countries and Pakistan is different among other Asian countries because of number of reasons as discussed in introduction with respect to its governance structure. We also have find interesting results as from other empirical studies recently a part of Pakistan perspective research and having number of important implications with respect of changes need to be made in Pakistan's governance structure. Findings shows there is impact of corporate governance on firm performance and market performance of firm also been effected with governance style.
\end{abstract}

Key words: corporate governance, firm performance, C.G theories in practice.

\section{Introduction}

Corporate governance(C.G) is a system or a network which sets certain orders or rules laid down for firms to be controlled and directed (Cadbury Committee, 1992). The company is owned by different people and run by different people as we know there are multiple persons attached with companies known as stakeholders and they may be involved with direct and indirect interests, which are justified with certain attentions involved to the firms. This arises the need of corporate governance to understand those rules by which the companies work and act in safe side of interests added by people to the companies they are attached with and of those who lead it.

Corporate governance is the system which makes sure that the finance suppliers to the company are satisfied about their investments which they made in company. Corporate governance is the framework of rules which makes sure that the rights and interests of financiers are not manipulated by the leading managers of that company in which they investment. Corporate governance is a big system which is developed with and has been developing with the time and making contributions in performance of companies and other

*Corresponding author.

Email: usman.shanu123@gmail.com variables. Research shows that the firm which has been governed better so they may have better performance as their payout ratios, are higher than of those which have been badly governed; therefore, corporate governance actually plays important role in firm performance (Denis and McConnell, 2003; Yasser, 2011). Jensen and Meckling were two famous researchers who introduced agency problem under agency theory in 1976 and started new research domain of corporate governance (Jensen and Meckling, 1976). At that time the corporate governance researches were largely focused on governance matters related to U.S based firms. However, later the researches came which focus on corporate governance matters in different countries of the world circa 1990s. Initial studies were conducted in developed part of the world like Japan, U.K, Germany, which are the major world economies, but now the focus of such studeis has been shifting towards emerging economies of the world like Pakistan, India and China to understand and study the need and importance of corporate governance.

This paper will help to understand corporate governance history and new researches in developed and developing countries which will help to build understanding of corporate governance with aspect of the- 
ories and different dimensions which have been contributed in field of corporations rules and laws by which they work and be controlled.

\subsection{Corporate Governance an Overview in Pakistan}

In Pakistan the rules and the regulations by which the firms will act are framed in code of C.G governance in early 2002 by the security and exchange commission of Pakistan (SECP) in the corporate governance; reforms in Pakistan. This code was developed by the joint aspect of SECP and ICAP. All the listed corporations in Pakistan are required to follow the instructions of this code and have to act upon the given provisions. The companys ordinance 1984 and the companies act 2017 and banking companys ordinance 1962 also provide the framework of different companies and provisions of governance mechanism, which have to be followed by the companies working in Pakistan. Securities \& Exchange Ordinance;(1969) is the based securities (law) and gives rules for protection of firms and investors, etc. The Securities \& Exchanges Act; (1996) empowered (SECP) as the regulator of the Capital Market \& controller of the Corporate Entities, whereas State bank (SBP) has made different implications code for the listed and non-listed banks which are to be followed by financing institutions as well. There is a separate code of governance for insurance companies as well.

The basic rights of shareholders and creditors are protected in Pakistan as the following, incorporated by ruling authorities and laws:

- Registration of shares is made under Central Depository Committee (CDC) and is very secure.

- Shareholders have right to participate in Annual General Meeting of the company and ask any information from managers related to their interest.

- Directors are selected by votes and might be removed by special resolution passed by sitting or holding rights (voting) shareholders.

- Shareholders having $(10 \%)$ or more voting rights have to disclose their ownership to understand the internal structure of firm.

- There should'nt be more than $(75 \%)$ of executive directors in BODs to project the minority shareholders interest.

- The code favor the institutional investors to be representative for meetings of board.

Comparing India with Pakistan, actually Pakistan can generate better by just making good improvements in governance in its real economy and it has done before in difficult time when the economy was in down turn, (Improved Governance; Dawn, 2010). Cheema (2003) asserts that issues are not actually between higher management and shareholders in Pakistan as shown mostly in academic literature, but agency problem is between the large shareholders and the other small or we can say the minority shareholders. So security and exchange commission of Pakistan (SECP) is trying to improve and make effective implementations of governance mechanism legislature by collaboration with Asian Development Bank and World Bank and so they require major researches in Pakistan about corporate governance.

\subsection{Corporate Governance Theories}

\subsubsection{Agency Theory}

This theory was developed by Jensen and Meckling (1976). This theory was defined as the relationship between the principles and agents, such as shareholders and agents such as the company executives and managers. The shareholders are the owners or the principles of the firms and they hire the agents who are managers or employees and they perform the task for their firms (Clarke, 2004). The agents are expected to perform work in best interest of their principles but here comes the problem where the control and power are separated and interest may not always align so here the theory gives link of corporate governance where there is a need of such rules to control and govern the firms with their owner's best interest (Padilla, 2000); same thing confirmed by Ross (1973) and Davis et al. (1997). However the managers and owners have different view about the risk and returns, because the studies confirm that the owners may want high return so they will like to have projects with higher risk profile to increase the firm's value; whereas managers want low risk profile projects to invest by the shareholders to ensure continued income and play at safe side, therefore resulting in conflict of interest. Whereas, studies also confirm the agents are self-interested and also have opportunistic behavior so they design those compensations which provide agents or managers with efficient incentives which in turn maximize the shareholder value (Bayless, 2009; Bhimani, 2008; Buck et al., 2008; Conyon, 2014; Eisenhardt, 1989; Holmstrom and Milgrom, 1994; Murphy, 1999; Ozkan, 2011). So the agency theory gives view of check and balance type of governance style. e.g. chairman and CEO are two different people and board should be independent.

\subsubsection{Managerial Power Theory}

As explained above, the compensation plans should be aligned with company's interest and the owners of firms should make sure the compensations are in their best interest to make mangers work accordingly to not hold all power in their hand and 
many studies describe the payperformance relationships (Tosi et al., 2000; Van Essen et al., 2015). MPT theory is most well known among all other theories, according to MPT, if balance of the power shifts towards the managers who act as agents, so they will behave opportunistically and that is why the compensation plans give great importance to control the managers and not letting them behave opportunistically (Bebchuk and Fried, 2003). If the powers of CEOs will have increased, so the board of directors will also get influenced by CEOs and they will not perform their duties as well as they should be performed and for such power shifts control the corporate governance is there to not let the power shift in wrong way and to control the firms rules in which manner the CEOs will work and perform their duties so that's why the CEO duality is considered to be not so good for other shareholders. CEO duality means at the same time, the person is chairman of board as well as a CEO of same firm so he may have extra power and he will set his own compensation very high and enjoy on behalf of other shareholders (Core et al., 1999; Jensen, 1993). Many studies confirm the positive relation of CEO duality and compensation and MPT shows that CEO duality has negative relation with board dependence and positive relation with power shifts (Boyd, 1994; Brick et al., 2006; Conyon, 2014; Core et al., 1999; Fahlenbrach, 2008; Van Essen et al., 2015). This theory gives view of governance by controlling the CEO power based on pay and shows $\mathrm{CEO}$ and chairman are two different persons.

\subsubsection{Stewardship Theory}

Stewardship theory has the roots in psychology and sociology which was defined by Davis et al. (1997) as a steward protects and maximizes shareholders wealth through firm performance, because by doing, the stewards utility functions are maximized. According to this theory, the managers working in organizations are actually protecting the firms and making profit by increasing the value to the shareholders so unlike the agency theory, this theory shows the managers are stewards to the firms and they work with the goals of organizations. This theory argues that top managers are actually satisfied and happy with organizations achievement and become more and more motivated. Argyris (1973) said that the agency theory gives view of economic individual, which means the individuals work in their own interest but on other side the Donaldson and Davis (1991) argued that according to stewardship theory the managers should be empowered fully to act in best interest of shareholders and should perform autonomously all tasks given to them and this is also unlike with managerial power theory. Daily et al. (2003) said that the managers want to protect their reputation attached with their market worth so they perform functions in order to increase the firm's financial performance. Shleifer and Vishny (1997) argued that the managers return finances back to the financers as soon as possible, in order to re-enter the finance whenever they needed to enhance their market reputation. This model of stewardship can be seen in Japan because those are hard workers. Moreover, this theory suggests that $\mathrm{CEO}$ and chairman should be the same person to reduce the agency cost and to protect shareholder wealth and watch more closely about the firm affairs and this is how he will play greater role as stewardship and many past studies have shown that the return of firms will improve. This theory reflects the governance style as CEO duality and CEO \& chairman is one person so he can view and control better as he has more knowledge about operations of organization.

\subsubsection{Stakeholder Theory}

This famous theory was developed by Freeman in 1984, which represents the firm with the broad range of stakeholders and shows responsibilities of firm to its direct and indirect stakeholders. This is not formal unified theory but has broad research range like organization, law, ethics, economics and political sciences. This theory was defined as any group or individual who can affect or is affected by the achievement of the organizations objectives. Unlike the agency theory in which managers and owners are separate, the theorist of stakeholder theory suggest that managers, suppliers, business partners are in network, in a relation to serve the organization (Freeman, 1999). Sundaram and Inkpen (2004) argue that the stakeholders required the management's attention. Nevertheless, Clarkson (1995) said that a company is a system and it is running for stakeholders so it should require to increase wealth for its shareholders. Donaldson and Davis (1991) said that the stakeholder theory shows managerial decision making process and the interest of the stakeholders are valued but not dominated on one another. This theory gives view of governance by protecting all stakeholders interest and not only the owners.

\subsubsection{Resource Dependency Theory}

Stakeholder theory focuses on group of individuals benefits, while the resource dependency theory focuses on the resources provided by directors. This theory was given by Salancik and Meindl (1984) and defined as, "organization enters in relation with other organizations because it has relied on their resources to achieve its own goals. Hillman et al. (2000) argue that the resource dependency theory shows the role of directors in providing the resources to the firm by their linkages in the external environment. Johnson et al. (1996) argued that the resource theorists focus on appointment of such independent representative for the firm to whom the firm can have benefits and without 
him the firm has that benefits on high cost, for example, a person outside from the law firm and if he will be the independent director to the firm so he may give his advices on legal or organizational laws so it will be costless and if he may not be the director to the firm so his advices will be on high cost, which has to be paid by the firm. Daily et al, 2003 said as high as the resources of the firm are, better will be its performance. So this theory gives view of governance as we can say the performance of the firm is the direct function of its resources which is provided by the directors who may be independent.

\subsubsection{Transaction Cost Theory}

Transaction cost theory was first drived by Cyert et al. (1963) and later theoretically described and exposed by Williamson (1989). This theory views the firm as a big organization having a lot of people in it with different objectives and different views. A firm can determine the function of its price and its production so the unit of analysis in this theory is transaction cost. This theory argues that managers behave opportunistically and arrange firms transactions to their interests (Williamson, 1996). This theory is viewed as the part of corporate governance and agency theory, unlike the resource dependency theory, which argues that directors give resources and will be costless but transaction cost theory argues that cost will be raised when you wish something to be done from someone for you. e.g. directors to run business that you own. At first, this theory was viewed as the decision of make or buy in production. It represents the governance as the net effect from external and internal transaction cost.

\subsubsection{Ethics Theories}

Like other fundamental theories there are some ethics theories about corporate governance which represent the firm as an ethical person. e.g. social contract theory, which is defined as "the society as a series of social contracts between members of society and society itself" (Gray et al., 1996). Another theory which is famous in governance ethics is legitimacy theory, which was defined as a generalized perception or assumption that the actions of an entity are desirable, proper, or appropriate with some socially constructed systems of norms, values, beliefs and definitions (Suchman, 1995). Both theories argue that the firm gets permission to operate in society and it has some ethical obligations like CSRs.

\section{Literature Review}

Past studies comprehensively discussed the issue regarding the good corporate practices. The impacts of governance on the firm performance and profitability have been discussed and identified in literature review. The purpose of this study is to analyze the impact of corporate governance on the firm performance. In this study we have studied the effectiveness of corporate governance variable as "Internal" which has already been discussed by different researcher in their research study.

Internal corporate governance has the greatest impact on firm performance and the profitability and compensation as compared to other variables. Due to limited time frame we have only discussed few variables of corporate governance and created hypothesis in accordance with the view of developing country like Pakistan and compare other Asian countries like Japan and China and also keeping view from developed countries like U.S which has a best known and developed corporate governance, however this study has been done in many countries but Pakistan is one different country as per reasons given below.

- Family type of ownership in firms seems to be common in Pakistan than in Korea \& Japan. Similarly, while Chinese companies have more institutional owners concentration than in Pakistan.

- Chinese are likely to be different in companies as the State usually has more or high stakes in large corporations but in Pakistan concentrated family ownership is maintained by non-govt shareholders giving way to private-owned firms because of high family ownership in Pakistan.

- Legal law situation and political environment unstability in Pakistan, so weaker system results in poor governance.

- Index of govt. effectiveness and index of regulatory quality which was estimated by the World Bank have been negative.

- Pakistan seems to be under the influence of IMF.

- Reported Transparency International, Pakistan's index never crosses 30 which is the Corruption Perception Index. So this is what makes Pakistan very interesting to study the governance in relation with different variables.

\subsection{Board Size}

There are various studies which indicate that large board sizes are less effective as compared to small board size. Anderson and Reeb (2003); Coles et al. (2008) argued that the cost of problem solving and coordination cost are high in large board size as compared to small and which leads to difficulty in making discussion. Eisenberg et al. (1998); Lipton and Lorsch (1992); Yermack (1996) indicated that there is a tendency in enhancing the firm performance if board size is small 
because it reduces the possibility of free riding. Eisenberg et al. (1998) also argued that the effect of board size for new firm and various range of firm effect their explanation. Mak and Kusnadi (2005) argued that there is negative relation between board size and firm performance. On the ground of above study the research hypothesis is formed as:

$H_{1}$ : There is a significant negative impact of Board size on firm performance.

\subsection{Board Independence}

Possible deviation between management and shareholder has been reduced by effective mechanism if there is an involvement of independent director on the corporate board and it leads to higher firm performance. John and Senbet (1998) investigated that if the involvement of more non-executive director in corporate board becomes more independent board. The study indicates that there is the negative relation between firm performance and board independency (Bhagat and Black, 2001). The result showed in past studies if board depends on more executive director there is possibility of high agency conflict and low firm performance. Another study revealed that number of more independent board members involved improves the firm performance. So on the above discussion following hypothesis is formed as:

$\mathrm{H}_{2}$ : There is positive relationship between independent director and firm performance.

\subsection{CEO Duality}

CEO duality refers to when a single person holds two different positions like as a CEO and board chairman. According to Berg and Smith (1978); Ehikioya (2009) there is always higher agency cost and conflict of interest when the same person having two position as a CEO and chairman of board and it is recommended that two different people should not occupy two different position. Another study argued that CEO duality gives the opportunity to CEO to take decisions without any undue influence of official structure. Elsayed (2007), indicated that corporate performance does not affect by CEO duality. Another research study indicates that CEO duality decreases the operational and financial performance of the firm (Jensen and Meckling, 1976; Kyereboah-Coleman and Biekpe, 2006; Nazir et al., 2009). According to Stewardship theory CEO duality should be prefered as one person having both posts will have internal as well as external cost and will also lower transaction cost. As Pakistan rules and laws are not very strong and have more family ownerships so we can hypothesis as:
$\mathrm{H}_{3}$ : There is a positive relationship between CEO duality and performance of firm.

\subsection{Board Meeting}

Frequent annual meetings of board director measure the potency of board activity. Conger et al. (1998) pointed out that firm performance increases when board of director frequently meets annually and they work for the best interest of shareholders. Another study indicated that it is not necessary for board of directors to meet frequently because it leads to heavy cost such as wastage of managerial time and directors remuneration and due to limited time frame they cannot share their ideas effectively. As in Pakistan normally directors meeting does not hold that frequently when firms performance is good and if performance is in a slump or there are industrial sector crises the meeting rating goes higher to meet the problem, otherwise as the country has family ownership and has CEO duality, the chairperson and executives are already interconnected. Based on the above research findings we formulate the following hypothesis as:

$\mathrm{H}_{4}$ : There is a negative relationship between frequently annual board meeting and firm performance.

\subsection{Ownership Structure}

Over the last Fifty years, a question arises whether the structure of corporate Governance is decentralized or centralized. In decentralized system control of the company is not in one hand of management or different shareholder or stakeholder have a control on it. On the other hand, in centralized system corporate ownership structure based on centralized management in which one or two persons have a control on it. Corporate Governance varies according to corporate structure. In Pakistan ownership structure of corporate is centralized. Jalil et al. (2010) suggested that there is significant and positive impact of corporate governance on the firm performance and can be increased by improving the ownership structure. Mayer (1996) investigated that ownership and control discriminate appearance of different financial system. We believe Pakistani firms perform well in family ownership because if there is diversity in board the firm will not perform well because of board size diversity so based on the above finding we select the following hypothesis as:

$\mathrm{H}_{5}$ : There is a significant positive impact of family ownership structure on the firm performance.

\subsection{Female Board Member}

Many studies have been conducted on Female board member as a Corporate Governance. Dutta and 
Bose (2007) suggested that there is a diversified characteristic in board if female member is involved in board. Smith et al. (2006) suggested three factors by which female members play a vital role in board. First, the understanding level of female member is greater as compared to men and such understanding has a great impact on board decision effectively. Second, community perception is associated with female board member. Third, when female member is appointed, other board members better understand the environment of business. Past study reveals such female board members have positive impact on firm performance but in Pakistan as family ownerships are high and directors give shares to their own wives and children to take soft corner in taxes and moreover in Pakistan females are unlikely to take such positions. So following hypothesis is that:

$H_{6}$ : Female board members have no impact on firm performance.

\subsection{Board Education Level}

The board plays a vital role as internally controlled system in firm Corporate Governance (Fama and Jensen, 1983). Firm performances depend upon management effective decision which is supervised by board members. So each board member has knowledge of management decision making process. Effective management decisions enhance the firm performance which requires those board members whose quality or characteristic significantly contribute in the firm decisions (Adams and Ferreira, 2007; Fairchild and Li, 2005; Nicholson and Kiel, 2004). As resource base theory gives view of corporate governance that the directors are playing part to give resources to the firm to out-perform from its competitors, moreover transaction cost theory suggests the same that cost will be lower by having such people attached with the firm to take decisions. Based on the above research study, following hypothesis is that:

$H_{7}$ : There is a positive relationship between board educational level and firm performance.

\subsection{Boards Compensation}

According to Jensen and Meckling (1976) Agency problem plays a key objective role in advance Corporate Governance. Agency theory reveals that there is always constraint between management objective and shareholder interest. Sometimes management adopts those policies which protect themselves not in favor of shareholder interest. In order to overcome such problem, it is essential to pay the compensation to management as Corporate Governance mechanism which encourages them and positively contributes in firm performance (Jensen, 1993). Based on the above study, we develop hypothesis as given below:

$H_{8}$ : Board compensation has positive impact on firm performance.

\subsection{CEO's Compensation}

Agency theory tends to involve CEO with arm length transaction. This predicts positive link between CEO compensation and firm performance. But according to managerial power theory, if the balance of power shifts towards CEOs, the relationship will be inverse. In Pakistani context, CEOs are considered to be more powerful than the board because they may be either the heads of the controlling families or may have strong ties with controlling shareholders (Javid and Iqbal, 2008; Kamran and Shah, 2014). In Pakistan it is normal to see that CEOs compensation are hardly changed even in bad situations but it gets higher when firm performs better so:

$\mathrm{H}_{9}$ : CEO compensation has positive impact on firm performance but firm performance does not influence the CEO compensation.

\subsection{Boards Experience}

Board members experience plays an important role in firm performance. Past study argued that experience of those at their higher average age is greater than the younger age members and such experience is helpful in making better decision of firm. Carlsson and Karlsson (1970) argued that firm performance is influenced by risky decision which has been made by old age board members because they are more autocratic and intrusive with decision making. Wegge et al. (2008) argued that those board members who have more experience will better survive with business environment and feel comfortable in a group even in uncertain situation, which will boost the firm performance. On the above discussion we develop research hypothesis as below:

$H_{10}$ : There is a positive relationship between board experience and firm performance.

\section{Methodology}

\subsection{Scale}

$R O A=\beta 0+\beta 1$ BoardSize $+\beta 2$ BoardInd $+\beta 3$ CEOD $u+$ $\beta 4$ Meetings $+\beta 5$ Ownership $+\beta 6$ Gender $+\beta 7$ BoardEdu $+\beta 8$ BoardComp $+\beta 9$ CEOComp $+\beta 10$ BoardExp $+\varepsilon i$ 
ROA is the return on assets which represents accounting performance and is used as proxy to measure this dependent variable in our model, and it is measured as ratio of income before interest and taxes to total assets. Board size is measured as total number of total directors present in the board which is mentioned in the annual reports of firms. Code of corporategovernance in the Pakistan encourages the representation of independent directors which is mandatory requirement after year 2013. BoardInd shows board independence and to measure this variable normally researchers use ratio to non executive directors of the board size to measuring the board independence. CEODu is the CEO duality, and it is presented as a dummy variable to be measured by taking the value of 1 if CEO is the chairman among the BODs and 0 for otherwise.

Meeting represents the board meeting frequency of firm. Ownership represents the firm ownership structure where it is measured as state ownership measured as Code 1 if Government is owner and 0 otherwise and can also be measured as the Ratio of shares held by director divided by total outstanding shares of firm and if firm is institutional concentrated so researchers measure this variable as shares held by (promoter and banks where promoter can be foreign institutions or non-promoter institutions)/Total shares held by institutions and if family ownership is to be measured so researchers use ownership of largest shareholder (which may be certain percentage numbers of shares) as proxy for ownership concentration and it is dummy variable which takes value 1 for family firms and 0 otherwise.

Achleitner et al. (2014); Anderson and Reeb (2003) argued, to define family firm which fulfills any 1 of the 2 given conditions, (1) a person or family group holds at least $25 \%$ of voting right which may be measured as the percentage of shares owned (directly or indirectly) and (2) two or more family members sitting in the board. Gender means the female board members and it is measured as the total number of women present on the board. BoardEdu is Boards educational level and it is measured as number of directors holding masters degrees and because Pakistan is a developing country so education level master is well to measure other than in developing countries usually researchers take this variable measure as by postgraduate degrees. CEO and board compensation in Pakistan, stock options are non-existent. CEOs are seemed to be paid base salary, cash bonuses and other benefits, and postemployment benefits so researchers use total compensation in sum of all components of compensation including cash and non cash perks. BoardExp is board experience and is measured by the ages of directors sitting in the board.

\section{Discussion}

This study is descriptive in nature so discussion is based on theories that we discussed above and links with empirical evidence will be compiled in this portion. Empirical evidences from other studies have shown that in Pakistan reforms are made in 2013 corporate governance when regulatory body has set to shown all independent directors in their annual financial reports to encourage the investor's interest in financial markets to invest with safeguard and protected feelings when there are independent directors in the board and agency theory purposes the same style of corporate governance where independent directors are part of board so it results in higher the ROE and also market worth in terms of EPS (Jensen and Murphy, 1990; Kyereboah-Coleman and Biekpe, 2006). In different studies it is commonly viewed the assumptions of MPT managerial power theory in Pakistani firms where the CEO duality having in firm so CEO may become so powerful that power is shifted towards the $\mathrm{CEO}$ and he sets his own compensation bit higher than the market and enjoys his power distance and influences the other directors as well; so this is normally viewed in family owned firms and it results in lower ROE in firms but at same time we have seen according to the transaction cost theory which says the cost will be lower when CEO duality is in power and stewardship theory also purposes the idea of CEO duality and taking it as positive that managers are working for firm and making their interests align with corporation success so when there is CEO duality the person will have more internal as well as external information so he will perform well functions and lead towards success so in results the ROE will increase and due to ROE the firm will able to distribute more dividend and which will lead to higher the EPS.

It is found that the implications of stakeholder theory do not exist in Pakistan where this theory talks about the protection of all stakeholders which includes direct and indirect shareholders as Pakistan has more family concentrated firms so the rights of minority shareholders are often exploited. Researchers have also shown in their research that the problem in Pakistan is not about conflict between the management and owners but the real problem in agency problem is actually in large and small shareholders which the researchers have also shown in their empirical finings. Results are consistent with many other previous studies (Core et al., 1999; Croci et al., 2012; Fahlenbrach, 2008; Kamran and Shah, 2014; Van Essen et al., 2015).

As MPT managerial power theory purposes to set such compensation patterns that power shift does not go toward CEO in such a way that he will try to exploit the firm resources and we see in different and most recent study from Pakistan of Sheikh et al. (2018) in CEO duality if firm performance goes lower as ROE 
gets lower so the CEO pay will not be decreased in accordance; the results across different models need to be explored further using more variables on family characteristics as discussed by(Bertrand and Schoar, 2006). We also use ROE relation with directors pay patterns which shows by other researches that directors may get lower benefits so relation found inverse, resource base theory says firm should involve those directors in its board that may bring those resources which will be higher in cost if they were not directors so actually if those people will be directors who have those resources which are needed by firm so the firm will perform more better in all aspects because directors provide all resources to the firm's managers. Same is described by cost transaction theory which says the cost will be less in all means and these theories talk about empowering CEO and chairman by CEO duality. In Pakistan the female board member does not influence the ROE as cultural trends. Board experience and education matter when talking about the relations with ROE and even with EPS which reflects positive trend with market and firm performance in relation with board experience as argued by Wegge (2008).

We found no evidence in Pakistan for CSR as proxy for ethics theories impact on ROE as proxy for firm performance and even for market performance of firm which noted with EPS. So for future directions, we recommend to work in relation of ethics theories by creating proxy of CSR in relation with firm performance and market performance of firm. Due to time and resources limitation we were not able to work on all variables of governance so we have discussed only few of them in relation to firm performance.

\section{References}

Achleitner, A.-K., Günther, N., Kaserer, C., and Siciliano, G. (2014). Real earnings management and accrual-based earnings management in family firms. European Accounting $R e-$ view, 23(3):431-461.

Adams, R. B. and Ferreira, D. (2007). A theory of friendly boards. The journal of finance, 62(1):217-250.

Anderson, R. C. and Reeb, D. M. (2003). Founding-family ownership and firm performance: evidence from the s\&p 500. The journal of finance, 58(3):1301-1328.

Argyris, C. (1973). Some limits of rational man organizational theory. Public Administration Review, pages 253-267.

Bayless, M. (2009). The myth of executive compensation: do shareholders get what they pay for? Applied Financial Economics, 19(10):795-808.

Bebchuk, L. A. and Fried, J. M. (2003). Executive compensation as an agency problem. Journal of economic perspectives, 17(3):71-92.
Berg, S. V. and Smith, S. K. (1978). Ceo and board chairman: A quantitative study of dual vs. unitary board leadership. Directors and Boards, 3(1):34-39.

Bertrand, M. and Schoar, A. (2006). The role of family in family firms. Journal of economic perspectives, 20(2):73-96.

Bhagat, S. and Black, B. (2001). The non-correlation between board independence and long-term firm performance. $J$. CorP. l., 27:231.

Bhimani, A. (2008). Making corporate governance count: the fusion of ethics and economic rationality. Journal of Management $\mathcal{E}$ Governance, 12(2):135-147.

Boyd, B. K. (1994). Board control and ceo compensation. Strategic management journal, 15(5):335-344.

Brick, I. E., Palmon, O., and Wald, J. K. (2006). Ceo compensation, director compensation, and firm performance: Evidence of cronyism? Journal of Corporate Finance, 12(3):403423.

Buck, T., Liu, X., and Skovoroda, R. (2008). Top executive pay and firm performance in china. Journal of International Business Studies, 39(5):833-850.

Carlsson, G. and Karlsson, K. (1970). Age, cohorts and the generation of generations. American Sociological Review, pages 710-718.

Cheema, A. (2003). Corporate governance in pakistan: issues and concerns. The Journal, 8(2):7-19.

Clarke, T. (2004). Theories of corporate governance. The Philosophical Foundations of Corporate Governance, Oxon.

Clarkson, M. E. (1995). A stakeholder framework for analyzing and evaluating corporate social performance. Academy of management review, 20(1):92-117.

Coles, J. L., Daniel, N. D., and Naveen, L. (2008). Boards: Does one size fit all? Journal of financial economics, 87(2):329-356.

Conger, J. A., Finegold, D., and Lawler, E. E. (1998). Appraising boardroom performance. Harvard business review, 76:136-164.

Conyon, M. J. (2014). Executive compensation and board governance in us firms. The Economic Journal, 124(574):F60 F89.

Core, J. E., Holthausen, R. W., and Larcker, D. F. (1999). Corporate governance, chief executive officer compensation, and firm performance1. Journal of financial economics, 51(3):371-406.

Croci, E., Gonenc, H., and Ozkan, N. (2012). Ceo compensation, family control, and institutional investors in continental europe. Journal of Banking E Finance, 36(12):33183335 .

Cyert, R. M., March, J. G., et al. (1963). A behavioral theory of the firm. Englewood Cliffs, NJ, 2:169-187. 
Daily, C. M., Dalton, D. R., and Cannella Jr, A. A. (2003). Corporate governance: Decades of dialogue and data. Academy of management review, 28(3):371-382.

Davis, J. H., Schoorman, F. D., and Donaldson, L. (1997). Toward a stewardship theory of management. Academy of Management review, 22(1):20-47.

Denis, D. K. and McConnell, J. J. (2003). International corporate governance. Journal of financial and quantitative analysis, 38(1):1-36.

Donaldson, L. and Davis, J. H. (1991). Stewardship theory or agency theory: Ceo governance and shareholder returns. Australian Journal of management, 16(1):49-64.

Dutta, P. and Bose, S. (2007). Gender diversity in the boardroom and financial performance of commercial banks: Evidence from bangladesh.

Ehikioya, B. I. (2009). Corporate governance structure and firm performance in developing economies: evidence from nigeria. Corporate Governance: The international journal of business in society, 9(3):231-243.

Eisenberg, T., Sundgren, S., and Wells, M. T. (1998). Larger board size and decreasing firm value in small firms1. Journal of financial economics, 48(1):35-54.

Eisenhardt, K. M. (1989). Agency theory: An assessment and review. Academy of management review, 14(1):57-74.

Elsayed, K. (2007). Does ceo duality really affect corporate performance? Corporate Governance: an international review, 15(6):1203-1214.

Fahlenbrach, R. (2008). Shareholder rights, boards, and ceo compensation. Review of Finance, 13(1):81-113.

Fairchild, L. and Li, J. (2005). Director quality and firm performance. Financial Review, 40(2):257-279.

Fama, E. F. and Jensen, M. C. (1983). Separation of ownership and control. The journal of law and Economics, 26(2):301-325.

Freeman, R. E. (1999). Divergent stakeholder theory. Academy of management review, 24(2):233-236.

Gray, R., Owen, D., and Adams, C. (1996). Accounting $\mathcal{E}$ accountability: changes and challenges in corporate social and environmental reporting. Prentice Hall.

Hillman, A. J., Cannella, A. A., and Paetzold, R. L. (2000). The resource dependence role of corporate directors: Strategic adaptation of board composition in response to environmental change. Journal of Management studies, 37(2):235256.

Holmstrom, B. and Milgrom, P. (1994). The firm as an incentive system. The American economic review, pages 972-991.

Jalil, M. A., Azam, F., and Rahman, M. K. (2010). Implementation mechanism of ethics in business organizations. International Business Research, 3(4):145.
Javid, A. Y. and Iqbal, R. (2008). Ownership concentration, corporate governance and firm performance: Evidence from pakistan. The Pakistan Development Review, pages 643659.

Jensen, M. C. (1993). The modern industrial revolution, exit, and the failure of internal control systems. the Journal of Finance, 48(3):831-880.

Jensen, M. C. and Meckling, W. H. (1976). Theory of the firm: Managerial behavior, agency costs and ownership structure. Journal of financial economics, 3(4):305-360.

Jensen, M. C. and Murphy, K. J. (1990). Performance pay and top-management incentives. Journal of political economy, 98(2):225-264.

John, K. and Senbet, L. W. (1998). Corporate governance and board effectiveness1. Journal of Banking $\mathcal{E}$ Finance, 22(4):371-403.

Johnson, J. L., Daily, C. M., and Ellstrand, A. E. (1996). Boards of directors: A review and research agenda. Journal of management, 22(3):409-438.

Kamran, K. and Shah, A. (2014). The impact of corporate governance and ownership structure on earnings management practices: Evidence from listed companies in pakistan.

Kyereboah-Coleman, A. and Biekpe, N. (2006). The relationship between board size, board composition, ceo duality and firm performance: Experience from ghana. Corporate Ownership and Control, 4(2):114-122.

Lipton, M. and Lorsch, J. W. (1992). A modest proposal for improved corporate governance. The business lawyer, pages 59-77.

Mak, Y. T. and Kusnadi, Y. (2005). Size really matters: Further evidence on the negative relationship between board size and firm value. Pacific-Basin Finance Journal, 13(3):301-318.

Mayer, C. (1996). Corporate governance, competition and performance.

Murphy, K. J. (1999). Executive compensation. Handbook of labor economics, 3:2485-2563.

Nazir, M. S., Haque, A., and Ali, S. (2009). Can board mechanism affect the firm value in pakistan. Corporate Ownership and Control, 6(3):308-317.

Nicholson, G. J. and Kiel, G. C. (2004). Breakthrough board performance: how to harness your boards intellectual capital [1]. Corporate Governance: The international journal of business in society, 4(1):5-23.

Ozkan, N. (2011). Ceo compensation and firm performance: An empirical investigation of uk panel data. European Financial Management, 17(2):260-285.

Ross, S. A. (1973). The economic theory of agency: The principal's problem. The American Economic Review, 63(2):134139. 
Salancik, G. R. and Meindl, J. R. (1984). Corporate attributions as strategic illusions of management control. Administrative science quarterly, pages 238-254.

Sheikh, M. F., Shah, S. Z. A., and Akbar, S. (2018). Firm performance, corporate governance and executive compensation in pakistan. Applied Economics, 50(18):2012-2027.

Shleifer, A. and Vishny, R. W. (1997). A survey of corporate governance. The journal of finance, 52(2):737-783.

Smith, N., Smith, V., and Verner, M. (2006). Do women in top management affect firm performance? a panel study of 2,500 danish firms. International Journal of productivity and Performance management, 55(7):569-593.

Suchman, M. C. (1995). Managing legitimacy: Strategic and institutional approaches. Academy of management review, 20(3):571-610.

Sundaram, A. K. and Inkpen, A. C. (2004). The corporate objective revisited. Organization science, 15(3):350-363.

Tosi, H. L., Werner, S., Katz, J. P., and Gomez-Mejia, L. R. (2000). How much does performance matter? a metaanalysis of ceo pay studies. Journal of Management, 26(2):301-339.
Van Essen, M., Otten, J., and Carberry, E. J. (2015). Assessing managerial power theory: A meta-analytic approach to understanding the determinants of ceo compensation. Journal of Management, 41(1):164-202.

Wegge, J., Roth, C., Neubach, B., Schmidt, K.-H., and Kanfer, R. (2008). Age and gender diversity as determinants of performance and health in a public organization: the role of task complexity and group size. Journal of Applied Psychology, 93(6):1301.

Williamson, O. E. (1989). Transaction cost economics. Handbook of industrial organization, 1:135-182.

Williamson, O. E. (1996). The mechanisms of governance. Oxford University Press.

Yasser, Q. R. (2011). Corporate governance and performance (a case study for pakistani communication sector). International Journal of Trade, Economics and Finance, 2(3):204.

Yermack, D. (1996). Higher market valuation of companies with a small board of directors. Journal of financial economics, 40(2):185-211. 